\title{
High Strength Hot Rolled Steel Sheet for Automobile - A Review
}

\author{
Nitesh Kumar*1, Anjani Kumar Singh ${ }^{2}$, Ajit kumar ${ }^{3}$, Sushil patel ${ }^{4}$ \\ ${ }^{1,3}$, M.Tech, (materials science and engineering) Scholar,National Institute of Foundry and Forge Technology \\ Hatia, Ranchi (Jharkhand) India 834003 \\ ${ }^{2}$ PhD Scholar, ${ }^{4}$ M.Tech, (foundry and forge technology) Scholar,National Institute of Foundry and Forge \\ Technology Hatia, Ranchi (Jharkhand) India -834003
}

\begin{abstract}
Large weight reduction by application of high strength steels to underbody parts can be expected since relatively thick sheets are now adopted. In several different approaches to improve press formability of high strength hot rolled steels are explained. The basic concept of mechanical property control and the performances of a couple of high strength hot rolled steels. The fatigue strength of the steel sheet with scale increases with the decrease in the roughness of the steel sheet surface. The fatigue strength of the sheared edge deteriorates with the increase in the fractured plane roughness of the sheared edge. In case of the microstructure consisting of pearlite and coarse carbides, these phases increase the fractured plane roughness through the connection of the micro-voids arising around them. Accordingly, the reduction of these phases is significant for improving the fatigue strength. Based on these findings, three types of the 780MPa grade high strength hot rolled steel sheet for truck frame use have been developed.

Keywords - Hot rolled steel sheet, microstructures, and mechanical tests.
\end{abstract}

\subsection{Hot rolled steel sheet}

\section{Introduction}

The thickness of hot rolled steel usually greater than $1.83 \mathrm{~mm}$ for unexposed surface. Hot rolled steel are used in making chassis and underbody component that are about $25 \%$ of the total weight of the car. For some component, crashworthiness is required. Since relatively thick sheets are used for these components, considerable weight reductions are expected. Safety is a major concern for the chassis. High durability and reliability are required as well as good press formability to their complicated shapes. The application of hot rolled high-strength steel sheets to the chassis components, which leads to considerable weight reduction, is expected to expand rapidly in the coming years. It is, therefore, demanded to be developed as hot rolled highstrength steel sheets with good press formability and fatigue strength [1].

There is an increasing demand for fuel consumption and the reduction of $\mathrm{CO}_{2}$ emissions of automobiles from the viewpoint of the environment. Weight reduction of auto-bodies has been promoted as well as an improvement of engine efficiency, reduction of friction and so on. Hot-rolled steel sheets are used for chassis and underbody components that account for $25 \%$ or so of the total weight of a car body, and for some structural components, to which crashworthiness is required. Since relatively thick sheets are used for these components, considerable weight reductions are expected. Because safety is a major concern for the chassis, high durability and reliability are required as well as good press formability to their complicated shapes.

This seems to be the reason why a gauge down of these components is less progressive than other parts, as is well known for exposed panels. The application of hot rolled high-strength steel sheets to the chassis components, which leads to considerable weight reduction, is expected to expand rapidly in the coming years. It is, therefore, demanded to develop as hot rolled high-strength steel sheets with good press formability and fatigue strength [4].

Hot-rolled high strength sheet steels have been applied to suspension parts in automobiles [6] for the weight reduction. A problem in press forming sheet steels having tensile strength of $780 \mathrm{MPa}$ grade was lack of stretch flange formability. [7] In general, stretch flange formability of high strength sheet steel can be improved by the increase of local elongation.[8] In the view point of microstructure, ferritic steel without pearlite and large cementites has superior local elongation since it has less stress-concentrating region [9] compared with multiphase microstructure such as dual-phase steel. Based on the knowledge, stretch flange formability of $780 \mathrm{MPa}$ grade sheet steel should be improved if microstructure of the steel can be controlled to be only ferrite without pearlite and large cementites. However, the precipitation-strengthening of ferrite up to 780MPa grade has not been achieved so far since very fine carbides are required [5].

Strength and rigidity are generally required in automobile parts. However, suspension and chassis parts must also meet durability-related requirements, including fatigue characteristics, corrosion resistance, and other properties. Therefore, unlike the auto body, which is made largely from cold rolled steel sheets, mainly heavy gauge hot rolled steel sheets are used in chassis applications. Moreover, as automobile weight reduction has proceeded, high strength materials with tensile strength of 440-590 MPa class have also been increasingly adopted in chassis applications, replacing mild steel[10]. 
Corrosion is degradation of materials' properties due to interactions with their environments, and corrosion of most metals (and many materials for that matter) is inevitable. The corrosion behavior of car body steel in service has been studied over many decades. Coating seems to be a good resolution but we should know that in car manufacturing, the deformation process during car body stamping also have a great contribution for development of corrosion on car parts. Due to that, galvannealed steel has been developed and has been used to reduce the effect of corrosion. They perform good formability and high strength at the same time but galvannealed steel is not suitable or practical to be used at all parts due to cost and properties some part required. It is essential to do more study in corrosion behavior and performance of the material in order to evaluate and improve the design, cost effectiveness and reliability of each material used. Study on the corrosion behavior of deformed steel for automobile parts in various environments shall be discussed further in this thesis. [1]

Automobiles play an important role in part of our daily life. This makes it necessary to incessantly try to reduce their production cost in line with the innovation of production technology. At the same time, measures are being taken toward the reduction of fuel cost and the improvement of safety so that eagerly-pursued harmony with the social and natural environment can be established. It is safe to say that thin steel sheets for automobiles have made progress in responding to the market needs. In recent years, it has become one of the most important tasks for automobiles to make the reduction in weight of auto bodies compatible with the improvement of crashworthiness, particularly with the aim of reducing $\mathrm{CO}_{2}$ gas emissions by improving fuel consumption. The applications of high strength steel sheets are expanding as one of the means of satisfying those demands conflicting with each other. Steel sheets for automobile components are required to have different strength characteristics from part to part. Except for the cases in which the effects of characteristic improvement due to an increase in steel sheet strength cannot be expected, including rigidity, corrosion, and fatigue strength at welded parts, enhancing the strength of steel sheets is considered to contribute to thinning, that is, weight reduction, of steel sheets [2].

\subsection{History}

In 1997, the Kyoto Protocol became the world`s first international agreement on the issue, producing commitments by principally European countries and japan to reduce their $\mathrm{CO}_{2}$ emission in 2012 by about $5 \%$ compared with 1990. Further discussions have been continued at the summits and international conferences, trying to determine additional and stricter targets, and to fashion a system in which all nations can participate.

Taking against global warming is the responsibility of current generations. we must act now to reduce $\mathrm{CO}_{2}$ emissions and develop the alternatives for fossil fuels to preserve the earth`s environment.

In japan, the $\mathrm{CO}_{2}$ emissions of the steel industry account for a little over $14 \%$ of the total, the highest proportion among all the industries since steel is essential for the society to achieve industrial development; there is a clear need to find a way to reduce $\mathrm{CO}_{2}$ emissions in manufacturing steel.

There is a big difference in $\mathrm{CO}_{2}$ volume between two methods being used to manufacture steel; making one ton of steel through a blast furnace method using iron ore and coal as its main feeds emits two tons of $\mathrm{CO}_{2}$ compared with less than 0.5 tons by an electric furnace method which is making steel through recycling of steel scrap. For manufacturing exactly the same type of steel, the $\mathrm{CO}_{2}$ emission from an electric furnace mill is one fourth of those by a blast furnace mill.

In 1995 , we brought the Utsunomiya works on stream, establishing basically almost the same product line-up and capacity that Tokyo Steel has today. During the15 years since 1995, we have got about a 440thousand-ton yearly average reduction in $\mathrm{CO}_{2}$ emissions over the 15 years through replacing a supply of steel products which had been produced by the blast furnace mills. Therefore, we consider that Tokyo Steel has actually achieved a reduction in $\mathrm{CO}_{2}$ emissions equivalent to $35 \%$ of its $1990 \mathrm{CO}_{2}$ emissions, which is evidently a huge reduction compared with the 5\% target set for Japan as a whole under the Kyoto Protocol. When we consider a substantial reduction of $\mathrm{CO}_{2}$ emissions, recycling of steel scrap should be further promoted in Japan [13].

According to the research in 1998 by the High Strength Steel Sheet Working Group, a substructure of the joint research society of Iron and Steel Institute of Japan and Society of Automotive Engineers of JAPAN, in 2002 , the 4th year, the following classes of steel strength were expected to be the average strength levels [3].

\subsection{Problem Statement}

In automobile industry, deformations of a steel sheet due to the applying external forces change the shape of metal and also alter the arrangement of the atom. These changes more or less may affect the properties of by improving the strength of the part and at the same time may develop more reactive region for the corrosion to occur. Generally, the deformed parts will show more corrosion damage compared to the flat part. It is also said that it tends to corrode rapidly as reported in many journals. Usually coating the part with paint may retain the part from corrosion for a period of time. However there is still a tendency for the corrosion to develop 
underneath the paint due to a lot of causes such as strain, residual stress or microstructure alteration during the stamping process and others. [1]

Therefore, it is essential to understanding the corrosion behavior of deformed automobile parts to avoid producing a low quality product due to short life cycle than specification. Proper study on this matter is highly necessary. [1]

\section{Steel Sheet Used In Automobile Industry}

Excellent press formability and weldability during assembling, fatigue resistance, corrosion resistance as complete vehicle, crashworthiness when involved in collision and other strength as component are some of the typical required characteristic of ferrous material used for outer body. Although these characteristics are required of the steel sheets themselves, many of the characteristics also need to be evaluated for the assembled auto body as a whole. Ferrous materials are generally considered to be general-purpose materials, but the required characteristics actually depend on the positions where they are used, and ferrous materials of different thickness, strength, and formability are used with or without galvanizing. Accordingly, almost no identical materials are used at different positions [11].

In addition to the essential functions of transportation and comfort, high fuel efficiency and emission control from the viewpoint of global environmental protection and safety and durability as people-friendly features have nowadays become necessary. Automobile weight reduction, improvement of crashworthiness and extended life of body parts are considered as the main approaches to achieving these goals. Respond to those needs in the automotive industry, steel manufacturers have been paying great efforts in developing suitable steel products for each automotive part [10].

\section{Grades, Mechanical Properties And Chemical Compositions And Applications [12]}

\subsection{Grade Summary:}

ASTM A36 is the most commonly available of the hot-rolled steels which has good overall mechanical properties, is easily fabricated and may be formed hot or cold. Due to the hot roll process the surface on this steel will be rough when compared to cold rolled. ASTM A36 yield strength is also significantly less than C1018 - meaning that it will bend much more quickly than C1018; also it is more difficult to machine than C1018.

Typical Applications: Trailers, Walkways, Ramps, Structural support, general fabrication. Products: Round Bar, Rectangular Bar, Square Bar, Angle, Channel, Beam and plate

Table 1 - Chemical analysis:-

\begin{tabular}{|c|c|c|c|c|}
\hline Element & $\mathrm{C}$ & $\mathrm{Mn}$ & $\mathrm{P}$ & $\mathrm{S}$ \\
\hline Wt.\% & .27 & .60 & .04 & .05 \\
\hline
\end{tabular}

Table 2 -Mechanical Properties

\begin{tabular}{|c|l|}
\hline Tensile Strength (PSI) & 45,000 Min \\
\hline Yield Point (PSI) & 36,000 Min \\
\hline Elongation & 23 \\
\hline
\end{tabular}

\subsection{Grade Summary:}

Grade C1010 is used in the manufacturing of Electric-Resistance Welded tube. Typically available Cold Rolled strip (16 gauge and lighter) and Hot Rolled strip (.083" walland heavier). This product can be obtained in the as-welded condition (flash-in) or in the flash-controlled condition.

Applications: Machinery stands, exhaust tubes, handles, hand rails, display stands, conveyor rollers.

Products: Round Tube Only

Table 3 - Chemical Analysis:

\begin{tabular}{|l|l|l|l|l|}
\hline Element & C & Mn & P & S \\
\hline Wt.\% & $.08 / .13$ & $.30 / .60$ & .035 & .035 \\
\hline
\end{tabular}

Table 4 - Mechanical Properties:

\begin{tabular}{|l|l|}
\hline Tensile Strength (PSI) & 24,000 \\
\hline Yield Point (PSI) & 43,000 \\
\hline Elongation & 28 \\
\hline
\end{tabular}


3.3 Grade Summary: The grades C1018 \&1020 are low carbon steel grades having higher manganese content than mild steel and various other low carbon steels. Higher manganese makes this better steel for carburized parts since it produces a harder and more uniform case. It also has higher mechanical properties, including Brinell hardness, and better machining characteristics. Special manufacturing controls result in a quality product suitable for applications involving forging, heat treating, cold drawing, machining, etc.

Applications: Gears, pinions, worms, kingpins, chain pins, ratchets, dogs, oil tool slips and liners, studs, anchor pins, special bolts, tie rods. Any carburized parts requiring hard surface and soft core Products: Round Bar Only

Table 5 - Chemical Analysis:

\begin{tabular}{|l|l|l|l|l|}
\hline Element & C & Mn & P & S \\
\hline Wt.\% & $.15 / .20$ & $.60 / .90$ & .04 & .05 \\
\hline
\end{tabular}

3.4 Grade Summary: Manufactured by cold forming flat rolled steel into tubular shapes and then welded. The material is maintained during process to prevent loss of structure or loss of physical properties across the weld area. The finished tube has a uniform wall thickness and equal strength throughout its length. The tubing is easy to machine and fabricate and it can be, bent or drawn, flattened or flared and drilled or punched. It is easily welded using all the commonly used practices. Structural Tube has a surface suitable for painting or plating.

Applications: structural support and parts, frames, racks, trailer beds and trailer components, structural components

Products: Square Tube and Rectangular Tube

Table 6- Chemical Analysis:

\begin{tabular}{|l|l|l|l|l|}
\hline Element & C & Mn & P & S \\
\hline Wt.\% & $.18 / .23$ & $.30 / .60$ & .040 & .050 \\
\hline
\end{tabular}

Table 7- Mechanical Properties

\begin{tabular}{|c|l|}
\hline Tensile Strength (PSI) & 87,000 \\
\hline Yield Point (PSI) & 72,000 \\
\hline Elongation & 10 \\
\hline
\end{tabular}

3.5 Grade Summary: Medium carbon steels suitable for machining, forging, heat treating, cold drawing, etc. When heat treated, 1045 provides greater strength than can be obtained from lower carbon steels. Grade C1045 can be hammer forged, machine ability is good, but forming and welding qualities are limited.

Applications: Axles, machinery parts, stud bolts, ordinary shafts, pinions, gears, rock screens, forming dies, tool shank

Products: Round Bar, Shafting Square Bar and Plate.

Table 8 - Chemical Analysis:

\begin{tabular}{|l|l|l|l|l|}
\hline Element & $\mathrm{C}$ & $\mathrm{Mn}$ & $\mathrm{P}$ & $\mathrm{S}$ \\
\hline Wt.\% & $.43 / .50$ & $.60 / .90$ & .040 & .050 \\
\hline
\end{tabular}

Table 9 - Mechanical Properties:

\begin{tabular}{|l|l|l|l|}
\hline Properties & Rolled & Normalized & Annealed \\
\hline $\begin{array}{l}\text { Tensile Strength } \\
\text { (PSI) }\end{array}$ & 90,000 & 87,000 & 80,000 \\
\hline $\begin{array}{l}\text { Tensile Strength } \\
\text { (PSI) }\end{array}$ & 59,000 & 58,000 & 48,000 \\
\hline Elongation & 26 & 28 & 30 \\
\hline Brinell hardness & 201 & 192 & 159 \\
\hline
\end{tabular}

3.6 Grade Summary: Grade C1141 is a medium-carbon steel with higher mechanical properties than other medium carbon steels, as well as free machining properties. It has a fine-grain structure, with high consistency and uniformity, and is high strength as-rolled. Because of the free machining properties, it is usually used in automatic screw machines.

Applications: Axles, Pins, Studs, Bolts, Shafts, Tie rods.

Products: Round Bar and Shafting 
Table 10 - Chemical Analysis:

\begin{tabular}{|l|l|l|l|l|}
\hline Element & $\mathrm{C}$ & $\mathrm{Mn}$ & $\mathrm{P}$ & $\mathrm{S}$ \\
\hline Wt.\% & $.37 / .45$ & $1.35 / 1.65$ & .04 & $.08-.13$ \\
\hline
\end{tabular}

Table 11 - Mechanical Properties:

\begin{tabular}{|l|l|l|l|}
\hline Properties & Rolled & Normalized & Annealed \\
\hline $\begin{array}{l}\text { Tensile } \\
\text { Strength (PSI) }\end{array}$ & 95,000 & 97,000 & 85,000 \\
\hline $\begin{array}{l}\text { Tensile } \\
\text { Strength (PSI) }\end{array}$ & 56,000 & 58,000 & 50,000 \\
\hline Elongation & 25 & 23 & 26 \\
\hline Brinell hardness & 192 & 201 & 174 \\
\hline
\end{tabular}

3.7 Grade Summary: Hot Rolled Commercial Quality Sheets (ASTM A1011) are produced from low carbon rimmed, capped or semi-skilled steel, and are intended for uses involving simple bending or moderate drawing and welding. They can be bent flat on themselves in any direction at room temperature without cracking on the outside of the bent portion.

Applications: From agricultural implements to automotive equipment, blower and ventilating systems, hot air registers, stub barrels and drums to bins and partitions, metal enclosures. Products: Flat Sheet Only.

Table 12- Chemical Analysis:

\begin{tabular}{|l|l|l|l|l|}
\hline Element & C & Mn & P & S \\
\hline Wt.\% & .15 & .60 & .030 & .035 \\
\hline
\end{tabular}

Grade Summary: Structural steel is a steel material or profile, formed with a specific shape or cross section and certain standards of chemical composition and mechanical properties. Structural steel shape, size, composition, strength, storage, etc., is regulated in most industrialized countries.

Applications: Structural, agricultural instruments, transportation equipment, and miscellaneous non-critical applications that involve mild cold bending, hot forming, punching and welding. Used where seams and other surface imperfections may be tolerated.

Products: Channel, Beam and Plate.

\subsection{Hot-rolled Steel Sheets Containing Retained Austenite}

\section{Characteristics of Hot Rolled Steel Sheet}

Press formability is the key factor to adopt higher strength steels, and elongation is considered to be the most appropriate mechanical property to express the press formability of high strength steels. Hot rolled steel sheets containing retained austenite (low-alloy TRIP type multi-phase steels; hereinafter referred to as low alloy TRIP steels) are high-strength steel sheets having large elongation. This large elongation, especially a large uniform elongation, is the result of a so called transformation-induced plasticity (TRIP) effect wherein strain concentration is avoided as a result of the transformation of retained austenite to hard martensite during press forming[15,16].

Fig.1 shows the effect of the volume fraction of retained austenite on the mechanical properties of steels [34]. The product of the strength TS and total elongation T.El of low alloy TRIP steels increases with the amount of retained austenite, whereas the product of TS and the local elongation L.El show little changes. It is, therefore, understood that the increase in total elongation is due to the increase in uniform elongation. The higher the stability of retained austenite which can be assessed as the amount of transformation of retained austenite during tensile deformation, the larger TS $\times$ T.El product can be obtained, as shown in Fig.2[17]. It can therefore be concluded that the elongation of low alloy TRIP steels is governed not only by the amount of retained austenite but also by its stability. The basic metallurgical concept to control the microstructure of low alloy TRIP steels and examples of mill scale production with performances such as weldability and fatigue properties. 


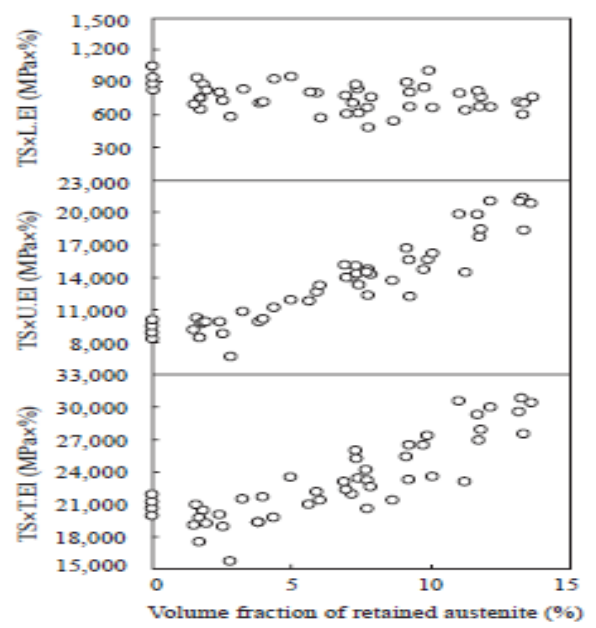

Fig. 1 Effect of the amount of retained austenite on strength-elongation combination of low alloy TRIP steels (T.El: total elongation, U.El: uniform elongation, L.El: local elongation) $[15,16]$

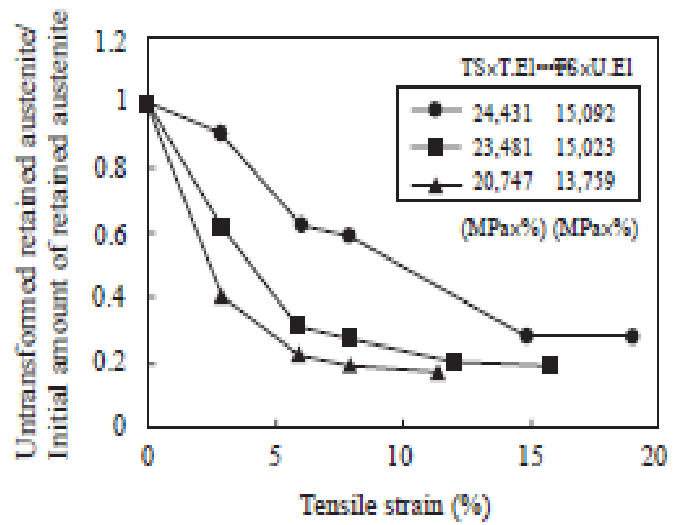

Fig. 2 Change in volume fraction of retained austenite as a function of tensile strain and the effect of stability of retained austenite on the strength-elongation combinations [17]

\subsubsection{Basic metallurgical concept to control the microstructure of hot-rolled steel sheets containing retained austenite}

In order to obtain enough retained austenite at an ambient temperature in steel without adding large amount of austenite former elements such as $\mathrm{Mn}$ and $\mathrm{Ni}$, it is necessary to enrich $\mathrm{C}$ to untransformed austenite for lowering the martensite transformation start temperature (MS temperature) of the austenite. As a result, the final microstructure consists of ferrite as the main phase, bainite, and retained austenite. Fig. 3 shows an example of the microstructure.

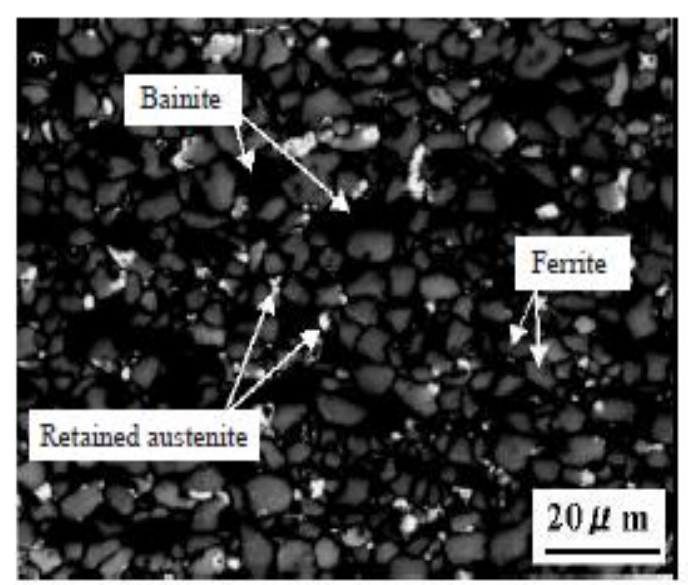

Fig. 3 A typical optical microstructure of as-hot-rolled low-alloy TRIP steel (special etching) [38] 
In order to obtain this microstructure in an actual production line, the following two transformation phenomena are used.

Ferrite transformation: As ferrite transformation proceeds, carbon atoms diffuse away from ferrite and enrich untransformed austenite. When the reaction proceeds under the local equilibrium between ferrite and austenite at the interface, the enrichment of carbon occurs in austenite at the vicinity of the interface [34]. As illustrated in Fig. 4, carbon enriched area is likely to remain untransformed. Therefore, increases in the area of the ferrite-austenite interface and the volume fraction of ferrite are effective for increasing the amount of retained austenite. The effect of the ratio between the volume fraction of ferrite and its grain size VPF/dPF on the product of strength and elongation $(\mathrm{TS} \times \mathrm{T}$.El) can be seen in Fig. 5[17]. Here, VPF and dPF are calculated using a metallurgical mode [35]. There is a correlation between the ratio VPF/dPF and the TS T.El product. The higher the value VPF/dPF, the larger the TS-T.El product can be obtained. Low temperature hot rolling and the controlling the cooling pattern on the run out table (ROT: the cooling zone after finish rolling) are effective to increase the volume fraction of ferrite and to refine ferrite grains at the same time. Cooling on the ROT contains a slow cooling around the ferrite transformation nose and as a result, the transformation of ferrite is effectively accelerated.

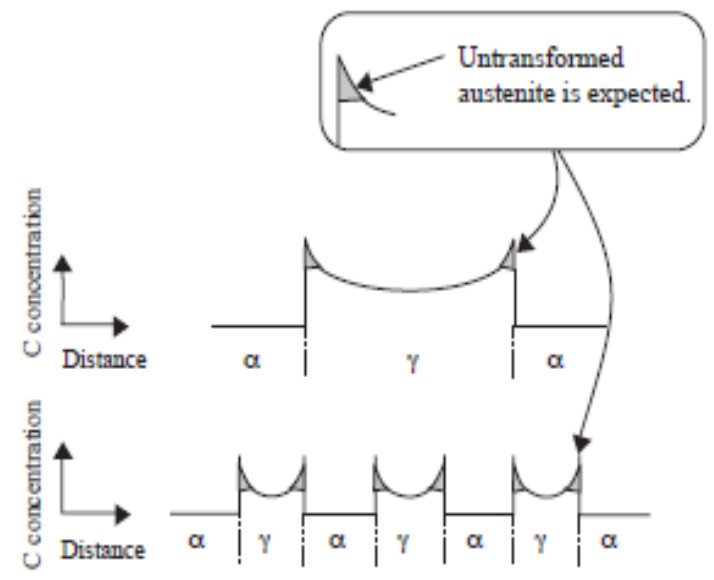

Fig. 4 Carbon concentration profiles in ferrite and austenite during the formation of ferrite.

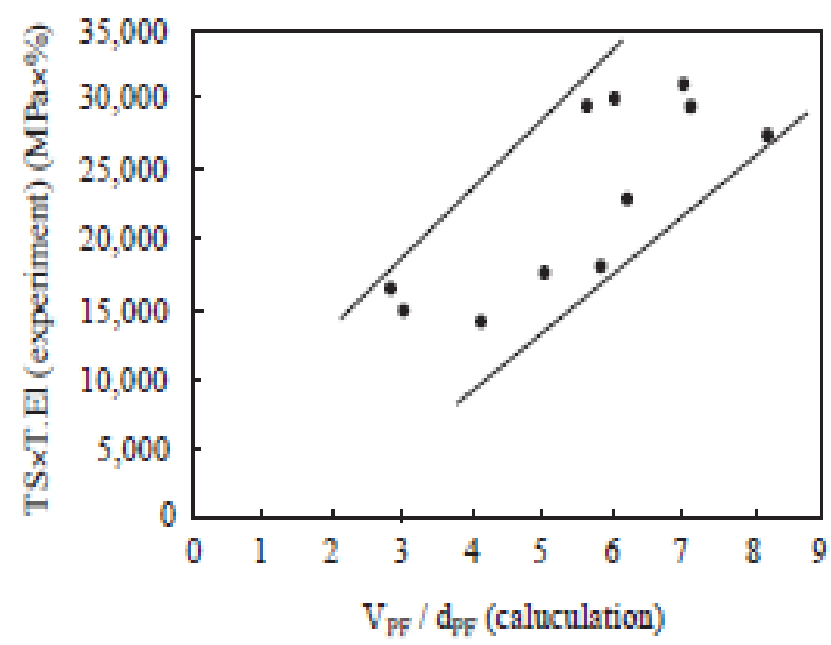

Fig. 5 Effect of the ratio between volume fraction and grain size of polygonal ferrite (VPE/dPF) on TS $\times$ T.El of as-hot-rolled low-alloy TRIP steels

(2)Bainite transformation: It is known from thermodynamics that ferrite transformation cannot lead to a sufficient enrichment of carbon to stabilize austenite at room temperature. Bainite transformation is, therefore, used to attain further carbon enrichment of austenite. When the formation of cementite is retarded by adding alloying element such as $\mathrm{Si}$, the enrichment of carbon in untransformed austenite proceeds further as bainite transformation advances and as a result, austenite is stabilized to retain at room temperature. When the untransformed austenite is not stable enough, martensite forms during cooling. The steel sheets are coiled at around $400^{\circ} \mathrm{C}$ after hot rolling and cooling to stabilize austenite effectively [34]. 


\subsubsection{Mill scale production of hot-rolled steel sheets containing retained austenite}

The developed hot-rolled steel sheets containing retained austenite are excellent in stretch formability due to their large elongation. However, good stretch flangeability is often required in the press forming of chassis components. As it is well established, stretch flangeability is influenced significantly by the microstructure. By lowering the carbon concentration of the steels and controlling hot rolling conditions, retained austenite and bainite are dispersed in fine ferrite grains, which improved stretch flangeability without deteriorating the elongation. Stretch flangeability is evaluated by hole expanding test, and the hole expansion ratio $\lambda$ between the original hole diameter $d o$ and the final hole diameter $d(\lambda(\%)=100 \times(d-d o) / d o)$ is used as its indicator.

The mechanical properties of the hot-rolled steel sheets containing retained austenite (elongation type and high burring type) produced on a commercial production line are shown in Table 4.1.1and Fig. 6. The elongation type steel has an elongation twice as large as that of conventional steel, while its whole expansion ratio is the same as that of the conventional steel. The burring type steel shows an elongation higher than that of conventional steel, while its whole expansion ratio is 1.4 times larger than that of the conventional steel. In addition to the above, good weldability and high fatigue resistance are also required of a steel sheet for automobile use. Two TS780MPa class hot-rolled steel sheets containing retained austenite of $2.3 \mathrm{~mm}$ in thickness were spot welded to each other using CF type electrodes of $8 \mathrm{~mm}$ in diameter under an electrode force of $625 \mathrm{kgf}$. In Fig. 7, the changes of the tensile shear strength (TSS) and cross-tension strength (CTS) of the weld joints are plotted against the welding current6). Nuggets formed at welding currents higher than $7 \mathrm{kA}$. $4,000 \mathrm{kgf}$ of TSS and 2,200 $\mathrm{kgf}$ of CTS are achieved at welding currents between 8.5 and $10 \mathrm{kA}$. Although CTS fluctuated above the expulsion current of $11 \mathrm{kA}$, it did not fall drastically and the strength of the weld joints was as high as that of conventional high-strength steel sheets.

Table 4.1.1 Mechanical property of as-hot-rolled low-alloy TRIP steels (examples of mill scale products)

\begin{tabular}{|c|c|c|c|}
\hline Properties & TS(MPa) & T.El & $\lambda(\%)$ \\
\hline Elongation type & 810 & 34 & 45 \\
\hline $\begin{array}{c}\text { High burning } \\
\text { type }\end{array}$ & 791 & 28 & 70 \\
\hline
\end{tabular}

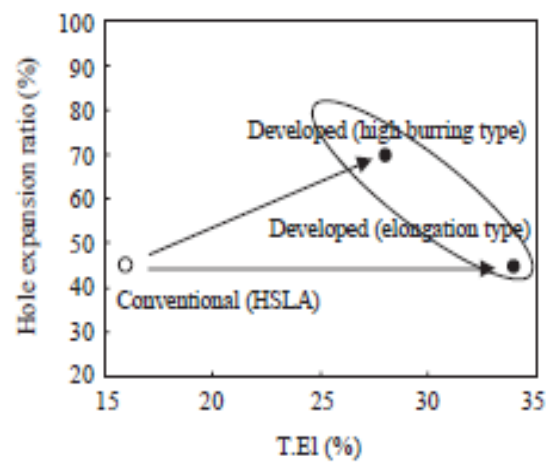

Fig. 6 Elongation-hole expansion ratio combination of developed as hot- rolled low-alloy TRIP steels [34]

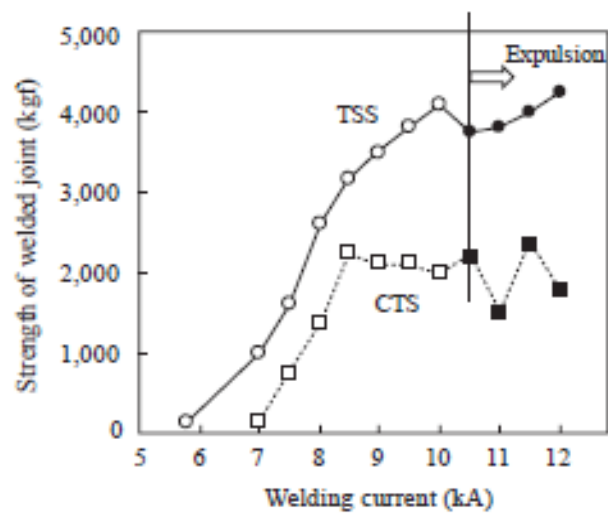

Fig. 7 Spot weldability of 780MPa grade as-hot-rolled low-alloy TRIP Steels 
High fatigue strength is also required for hot-rolled steel sheets for chassis components. DP steel is widely known to show high fatigue strength [18]. The fatigue strength of DP steel is higher than that of precipitationhardened steel or fully bainitic steel as a consequence of cyclic hardening at the initial stage and small softening due to stable fine dislocation cell structure produced during the initial cyclic hardening. It is also known that dispersed fine martensite particle retards the propagation of fatigue cracks and the $\alpha$-phase strengthened by $\mathrm{Si}$ suppresses the initiation of fatigue cracks [18]. Here, the cyclic hardening means the increase in stress amplitude during a strain controlled fatigue test. The same effect is observed for steels containing retained austenite. In addition to this, the deformation-induced transformation of retained austenite, which occurs at the vicinity of a stress concentrated area, can relax the stress field and introduce a compressive stress which is also considered to improve fatigue strength [25]. In Fig. 8the results of plane bending fatigue test of TS780MPa class hot-rolled steel sheets containing retained austenite of 2.3 and $2.7 \mathrm{~mm}$ in thickness are compared with conventional 540 and 590MPa hot-rolled steel sheets with the same level of elongation [19]. The fatigue strength of the developed high-strength steel sheets after $2 \times 106$ cycles was $400 \mathrm{MPa}$ that is 1.4 to 1.5 times higher than that of conventional steel sheets with the same press formability.

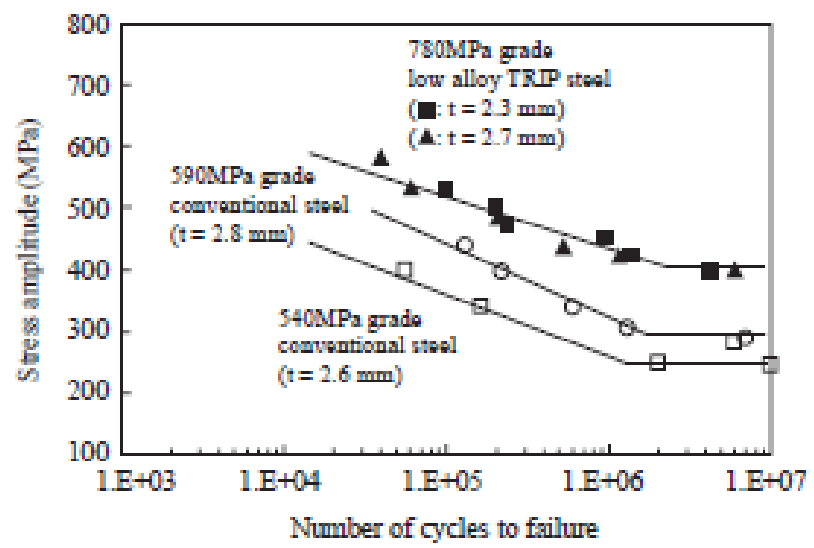

Fig. 8 Fatigue properties of 780MPa grade as-hot-rolled low-alloy TRIP steels (plane bending fatigue test)

\section{High Strength Steel Sheets For Chassis}

Fatigue strength and corrosion resistance as well as rigidity are strongly required for chassis as described above. Hot rolled steels are widely used for chassis because relatively thick gauges are required [36].

\subsection{Highly ductile hot-rolled steel sheets}

The most ductile steel among hot rolled high strength steel sheets is low alloy TRIP steel (retained austenite steel). When steel sheets are used as hot-rolled, they are cooled after finishing hot rolling and coiled at about $400{ }^{\circ} \mathrm{C}$ allowing bainite transformation proceed to stabilize austenite. The elongation of low alloy TRIP steel is closely interrelated with the volume fraction of retained austenite. However, when steel sheets are used as hot-rolled, it is effective to enlarge the ratio between the volume fraction of austenite and ferrite grain size by optimizing the hot rolling conditions and successive cooling conditions [35].Hot-rolled TRIP steel is not only highly ductile but also excellent in crash energy absorbing property as described above. In addition, because of its good fatigue resistance, it can be expected to find various applications. Since low alloy TRIP steels have mixed microstructure of hard and soft phases, they are generally considered to be inferior in stretch flangeability as in expanding pierced hole. As reported in this issue, low alloy TRIP steels with high stretch flangeability have also been developed which have overcome the above-described defects by controlling the chemical composition and microstructure of the steel.

\subsection{High burring hot-rolled steel sheets}

Stretch flanging is often applied to under-body parts in which shared edges are stretched. As described above, this stretch flangeability is evaluated by the whole expansion test. Since the higher the homogeneity of microstructure, the better the stretch flangeability can be obtained, high strength steel sheets with an enhanced stretch flangeability (high burring hot-rolled steel sheets) have been developed by controlling the microstructure to ferrite + bainite or bainite single phase. It is also worth noting that refinement of cementite particles, inevitably present in conventional steels, is effective to improve stretch flangeability. High burring steels of around up to $590 \mathrm{MPa}$ in tensile strength have been developed in which cementite particles are refined through alloy addition such as $\mathrm{Si}$ which has very low or no solubility in cementite resulting in a retardation of the growth of cementite particles[20]. Furthermore, as reported in this issue, $780 \mathrm{MPa}$ class low carbons high strength steel sheets with high hole expansivity have also been developed and commercialized. 


\subsection{High strength steel sheets with excellent weldability}

When arc welding is used to join steel sheets, attention should be given to the fact that the strength properties could be deteriorated by the softening at heat affected zone (HAZ) of the welding. Anti HAZ softening steels have been developed by adding $\mathrm{Nb}$ and Mo which interact with dislocations preventing their annihilation and accelerating the formation of $(\mathrm{Nb}, \mathrm{Mo}) \mathrm{C}$ complex precipitates on the dislocations [21].

\subsection{High fatigue strength steel sheets}

Under body structural parts including wheel discs and suspension arms, are required to have high fatigue strength. It is common to encounter fatigue problems at welded joints, shared edges, and stress concentrated areas depending on the geometry. Since the fatigue life is considered to be determined rather by the initiation of fatigue cracks than the propagation of them in the case of thin steel sheets, it is effective to increase the fatigue strength of bulk steels.

It is well established that DP steels with mixed microstructures of Si solid solution hardened ferrite and finely dispersed hard martensite exhibit high fatigue strength [22]. Low-cycle fatigue experiments tells us that $\mathrm{Si}$ solid solution hardened hot-rolled DP steels show high and steady cyclic stress due to the fact that the dislocation cell structure produced at a very early stage of the fatigue test is stable. This high cyclic resistance seems to prevent the initiation of fatigue cracks. DP steels with excellent combination of ductility and fatigue strength have been developed by decreasing the bulky bainite microstructure and diminishing an abnormal grain structure of a mixture of fine and coarse grains near the surface of the sheets [23]. DP steels with the strength up to $780 \mathrm{MPa}$ have been developed and commercialized now. Fatigue strength is known to relate closely with cyclic yield stress (Fig. [24]. Low alloy TRIP steels also show higher fatigue strength as DP steels than other high strength steels [23]. The high fatigue strength of low alloy TRIP steels is supported not only by the hardening of ferrite, the major phase as in DP steels, by $\mathrm{Si}$, but also by the compressive residual stress introduced by the expansion due to martensite transformation of retained austenite during cyclic loading [25].

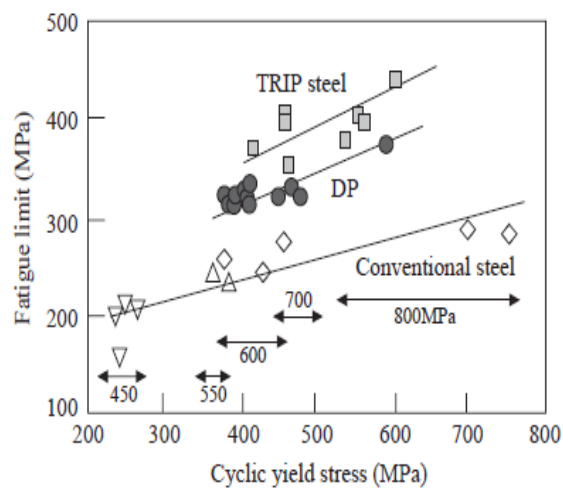

Fig. 9 Effect of cyclic yield stress on fatigue limit of high strength steels [14]

Steels with $\mathrm{Cu}$ in solid-solution have also been reported to show very high fatigue limit ratios (fatigue strength/tensile strength), due to the retardation of recovery during cyclic loading [26].

\section{Development Of 780mpa Class High Burring Hot-Rolled Steel Sheets}

Increase of load capacity for trucks by weight reduction of the body has been required to cut down transportation cost. The weight reduction of truck body is feasible in terms of the application of high strength steel sheet to body. Especially, the application to truck frame is important because it is heavy.

The required properties of steel sheet for truck frame use are press formability and fatigue strength. Bendability, stretch ability and stretch-flangeability are important for the press forming of truck body. These properties have been well investigated concerning the application of high strength steel sheets to passenger car body (1-4). The findings obtained by these investigations are also applicable to the steel sheet for truck frame use.

As for fatigue strength, the fatigue strength of steel sheet with scale is significant because the steel sheet is painted without pickling to remove the surface scale. The fatigue strength of sheared edges is also important since truck frame has punched holes shown in Fig.1. However, investigations on the fatigue strength of high strength steel sheet for truck frame use are relatively few (5-8), and the value of fatigue strength is not sufficient. [32] 


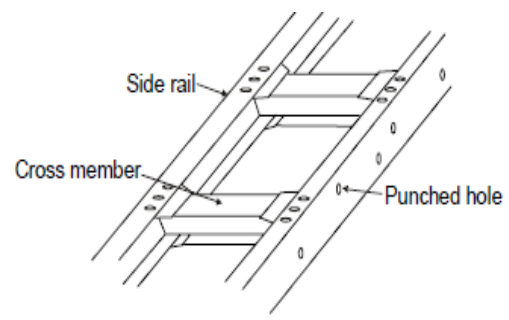

Fig.10 Schematic illustration of truck frame [32]

Application of 780MPa class hot-rolled steel sheets to underbody components such as lower suspension arm is being studied. The final shape of such components requires a very high stretch flangeability as well as a large elongation. For this purpose, the development of a steel sheet satisfying the conditions El $>20 \%$ and $\lambda>80 \%$ at the same time is required. The method to control the microstructure through the optimization of steel chemistry and hot rolling conditions was studied and, as a result, a 780MPa class high-burring hot rolled steel sheet with a combination of an excellent elongation and a very high stretch flangeability was developed.

\subsection{Basic metallurgy for controlling microstructure of high burring hot-rolled steel sheet}

Both good elongation and high stretch flangeability are indispensable for the press forming of underbody components such as a lower arm (see Fig. 9). In general, these properties are deteriorated with increasing the strength of steel [27, 28]. Although it is possible to enhance either of these two properties by controlling the microstructure [29], the method of controlling the microstructure to enhance both of them at the same time is not well established. Although it is suitable to enhance the elongation steels with mixed microstructures of soft ferrite (F) and hard phases such as martensite (M) etc, show poor stretch flangeability. Steels with acicular ferrite (A.F.) single phase microstructure, on the other hand, are suitable for enhancing stretch flangeability, which is governed by local ductility, but not for elongation (see Fig. 10). The authors then studied steel chemistry and hot rolling conditions for the purpose of finding out the optimum microstructure with which a good combination of elongation and stretch flangeability can be obtained. It was clarified from the study that the combination can be obtained when the microstructure is a mixture of ferrite and bainite in which the hardness difference between the two phases is minimized by solution hardening to make themicrostructure as uniform as possible. The following conditions are adopted to maintain the microstructure.

1. In order to enhance the formation of ferrite and to control the shape of ferrite, the amount of austenite former elements such as carbon and manganese are reduced, and a two-step cooling at the ROT is adopted. In addition,

2. The formation of an undesirable hard phase is suppressed by reducing the carbon content.

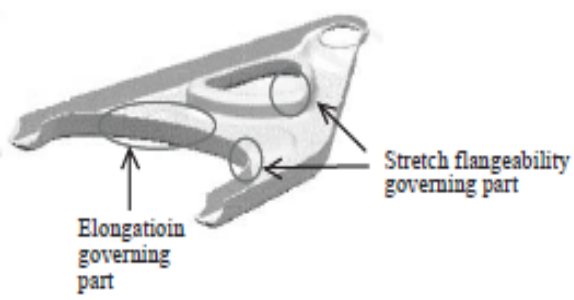

Fig. 11 Appearance and required forming properties of a lower arm

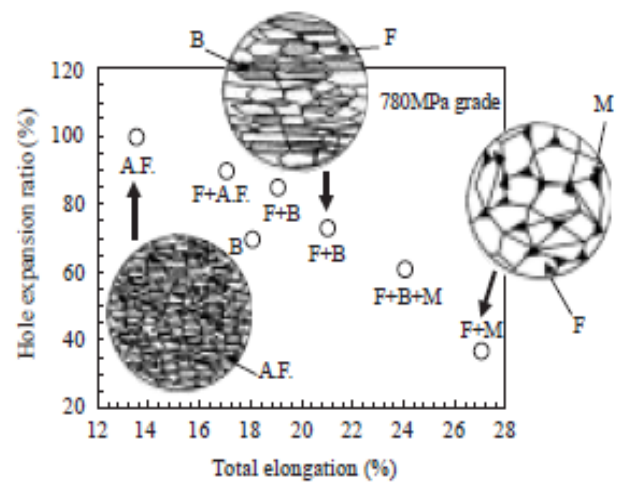

Fig. 12 Relations between total elongation and whole expansion ratio of $780 \mathrm{MPa}$ as-hot-rolled steels, and their microstructural feature 


\subsection{Mill trial of high-burring hot-rolled steel sheet}

On the basis of the above metallurgical concept, a mill trial of the high-burring- hot-rolled steel sheet was conducted. Table 6.2.1 shows the mechanical properties of the developed product in comparison with those of a conventional product.As a result of the reduced contents of $\mathrm{C}$ and $\mathrm{Mn}$, the Ar3 transformation temperature [30] of the developed steel sheet is raised by $53^{\circ} \mathrm{C}$, and thus the formation of ferrite is accelerated. The reduced content of Mn has proved effective, at the same time, for inhibiting the segregation of Mn during casting and as a consequence, enhancing the uniformity of microstructure. As a result, a good combination of elongation and stretch flangeability were obtained, meeting the target, $\mathrm{El}>20 \%$ and $\lambda>80 \%$, as seen in Fig. 11 .

Table 6.2.1 Comparison of mechanical properties between developed and conventional 780MPa grade high burring steels

\begin{tabular}{|l|l|l|l|l|}
\hline & $\mathrm{A}_{\mathrm{r} 3}$ & $\begin{array}{l}\text { ROT } \\
2 \text { steps }\end{array}$ & $\begin{array}{l}\text { TS } \\
(\mathrm{MPa})\end{array}$ & $\mathrm{EI}(\%)$ \\
\hline Developed & 789 & Yes & 797 & 22 \\
\hline Conventional & 736 & No & 795 & 19 \\
\hline
\end{tabular}

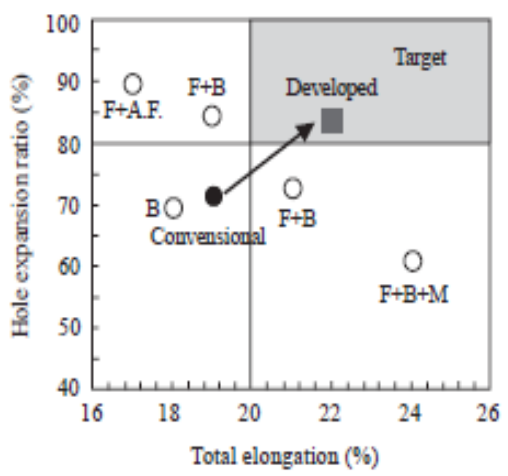

Fig. 11 Combination between total elongation and hole expansion ratio of developed 780MPa steel An example of the microstructure of the developed steel is compared with conventional steel in Fig. 12. It can be seen in the pictures that the microstructure of the developed steel is a mixture of ferrite and bainite, and that the volume fraction of ferrite is higher and more polygonal than the conventional steel.

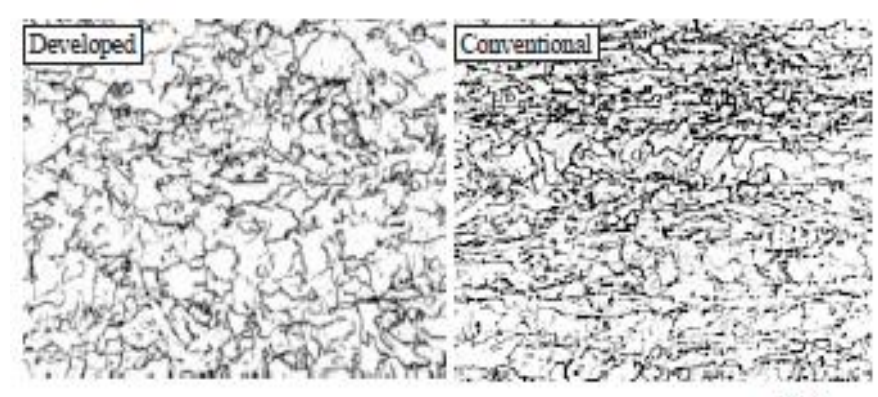

$20 \mu \mathrm{m}$

Fig. 12 Microstructures of developed and conventional 780MPa grade steels

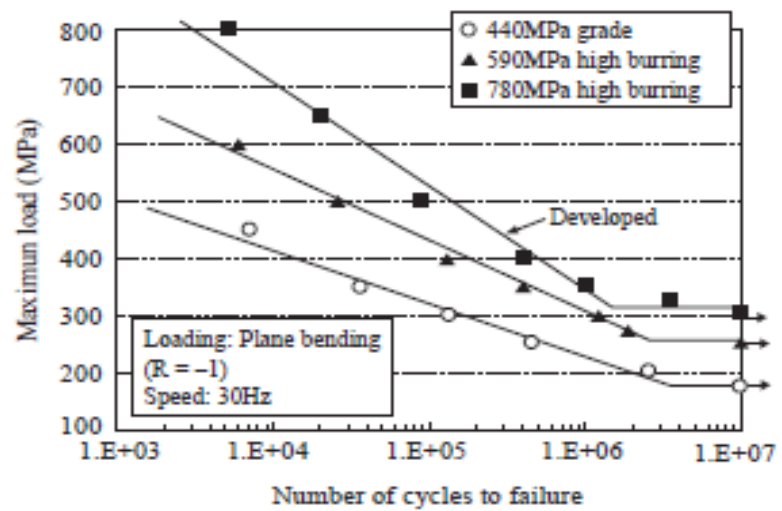

Fig. 13 Fatigue property of developed 780MPa grade high burring steel (plane bending fatigue test) 


\begin{tabular}{|l|l|l|l|}
\multicolumn{5}{|c|}{ Table 6.2.2 Fatigue limit ratio of developed steel } \\
\hline Steel & $440 \mathrm{MPa}$ & $\begin{array}{l}590 \mathrm{MPa} \\
\text { High burning } \\
\text { (conventional) }\end{array}$ & $\begin{array}{l}\text { High burning } \\
\text { (developed) }\end{array}$ \\
\hline $\begin{array}{l}\text { Fatigue limit } \\
\text { ratio }\end{array}$ & 0.38 & 0.42 & 0.40 \\
\hline
\end{tabular}

Fatigue limit $=\left(\right.$ fatigue strength at $10^{7}$ cycles $) / T S$

Fatigue property of the developed steel was compared with a $590 \mathrm{MPa}$ class high-burring steel sheet and $440 \mathrm{MPa}$ class conventional steel in Fig. 13. With respect to fatigue limit ratio, which is defined as the ratio between the fatigue strength of a steel sheet after 107 cycles and its tensile strength, it is clear that the developed steel sheet does not show any significant deterioration of the fatigue limit ratio in spite of its high strength from the result of a plane bending fatigue test under a stress ratio of -1 as shown in Table 6.2.2. In the developed steel, the strengthening is fully reflected in the fatigue properties.

\section{Applications}

Hot Rolled Steels are used where heavy thickness, strength levels, and formability are required. Many unexposed structural applications exist in automotive, appliance and manufacturing markets. These include frame components, brackets, brake components, wheels, clutch plates, tubing, and compressor shells. Construction, industrial machinery, agricultural equipment, railroad, and ship building are all areas where Hot Rolled Steels are used for panels, frames, and component parts [37].

\section{Problem Identification}

Deformations of sheet steel for automobile parts by applying external forces do not only change the shape of metal but also alter the arrangement of atom. These changes may affect the properties; by improving the strength of the part due to cold work while at the same time may develop a more reactive region for corrosion to occur. Cold working causes an increase in the internal energy level of the steel and deformation slip on the surface of steel. It is expected that cold working should influence surface film formation and cause some changes in corrosion attack. In general, the deformed parts shows more corrosion damage than the flat part and the corrosion in deformed parts tends to proceed rapidly as reported in many journals. Even though generally coating the part with paint shall retain the part from corrosion for some time, however there is a tendency for corrosion to develop beneath the paint due to strain, residual stress or microstructure alteration during the stamping process and the consequence result is disaster.

Therefore, understanding the corrosion behavior of deformed automobile parts is essential to avoid producing low quality product due to short life cycle than specification. Proper study on this matter is highly demanding. [31]

\subsection{Significant Study}

Deformation of sheet metal of automobile parts has a high potential of getting corroded faster than undeformed parts due to various factors. One of the main factors contributing to corrosion behavior is the environment condition. Various degrees of acidic and alkaline environment may exist during the fabrication process or storage. Therefore, it is essential to investigate the behavior and causes to corrosion of deformed steel in this environments. The main objectives of study are as follows: To study the corrosion behavior of deformed steels for automotive parts in various environments. [31]

\section{Conclusions}

The weight reduction of underbody components is expected to have a considerable contribution in the weight reduction of an auto body in the near future. Development of hot-rolled steel sheets with excellent press formability and fatigue strength are indispensable. The hot-rolled steel sheets with retained austenite and the high burring hot-rolled steel sheet presented in this paper are expected to contribute significantly to the weight reduction of an auto-body when they are applied widely to its components.

\section{References}

[1] Corrosion and Mechanical Properties Study of Car Steel Sheet Ahmad Basyir Bin Sadan 06 December 2010.

[2] Manabu Takahashi Technical Report No. 88 July 2003udc 699. 14. 018. 295 - 415: 629 . 11. 011

[3] Mizui, N.: Ferrum. 4(12), 856(1999)

[4] Manabu Takahashi, Osamu Kawano, TerukiHayashida, Riki Okamoto Hirokazu Taniguchi Nippon Steel Technical Report No. 88 July 2003,Udc 669. 14. 018. 295 - $415: 629$. 11. 011

[5] YoshimasaFunakaw), Tsuyoshi Shiozaki, Isij International, Vol. 44 (2004), No. 11, Pp. 1945-1951

[6] S. Hashimoto: J. Jsae, 54 (2000), No.1, 39. 3

[7] K. Yamazaki and K. Koyama: J. Jpn. Technol. Plast., 35 (1994), No. 404, 1036.

[8] K. Matsudo, Y. Uchida, M. Yoshida and K. Osawa: J. Jpn. Technol.Plast.,14 (1973), No. 146, 201.

[9] T. Inoue and S. Kinoshita: J. Jpn. Technol. Plast., 14 (1973), No.147, 291. 
[10] (Seto Kazuhiro, FunakawaYoshimasa, Kaneko Shinjiro,Jfe Technical Report No. 10 (Dec. 2007))

[11] (K. Sakata, S. Matsuka and K. Sato 2003).

[12] www.Metalsupermarkets.Com/Metals/Consumer-Guide/Hot-Rolled-Grades/

[13] (Hot Rolled Mild Steel Sheets \& Steel Strips, 2013.04.01)

[14] Anabu Takahashi Nippon Steel Technical Report No. 88 July 2003 Udc 699. 14 . 018. 295 - 415: 629. 11.011

[15] Zackay, V. F., Parker, E. R., Fahr, D., Bush, R.: Trans. Asm. 60, 252(1967)

[16] Hiwatashi, S., Takahashi, M., Sakuma, Y., Usuda, M.: Proc. of Int. Conf. on Automotive Technology and Automation. Germany, 1993,P.263.

[17] Kawano, O., Wakita, J., Esaka, K., Abe, H.: Tetsu-To-Hagané. 82(3), 56 (1996)

[18] Mizui, M.: J. of the Soc. of Materials Science Japan. 38, 15(1989)

[19] Sakuma, Y., Kimura, N., Itami, J., Hiwatashi, S., Kawano, O., Sakata, K.: ShinnittetsuGiho. (354), 17(1994)

[20] Matsuzu, N., Itami, A., Koyama, K.: Sae Tech

[21] Tomokiyo, T., Taniguchi, Y., Yamazaki, K., Tanaba, H., Anai, I.: Camp- Isij. 13, 127 (2000)

[22] Mizui, M.: Material. 38, 15 (1989)

[23] Mizui, M., Takahashi, M.: Camp-Isij. 5, 1867 (1992)

[24] Kishida, H.: ShinnittetsuGiho, (371), 13 (1992)

[25] Yokoi, T., Kawasaki, K., Takahashi, M., Koyama, K., Mizui, M.: Jsae Review. 17, 191 (1996)

[26] Yokoi, T., Takahashi, M., Maruyama, N., Sugiyama, M.: J. of Mat. Sci. 36, 5757 (2001)

[27] Takechi, H.: Tetsu-To-Hagané. 68(9), 1244(1982)

[28] Hayashi, H.: J. of the Japan Soc. For Technology of Plasticity. 40(457), 87(1999)

[29] Haji, J.: Camp-Isij. 6, 1698(1993)

[30] Kozasu, I.: Controlled Rolling And Controlled Cooling. ChijinShokan

[31] http://eprints.utm.my/9629/4/MohdFauziMFK M2008CHAP1.pdf

[32] Kunikazu Tomita, Tsuyoshi Shiozaki, Toshiaki Urabe, Akihide Yoshitake ,Seoul 2000 FISITA World Automotive Congress June 12-15, 2000, Seoul, Korea)

[33] Kawano, O., Wakita, J., Esaka, K., Abe, H.: Tetsu-to-Hagané. 82(3), 56 (1996)

[34] Kawano, O., Esaka, K., Katoh, S., Abe, H., Wakita, J., Takahashi, M., Katagami, K., Harada, S.: SeitetsuKenkyu. (329), 15(1988)

[35] Esaka, K., Wakita, J., Takahashi, M., Kawano, O., Harada, S.: SeitetsuKenkyu. (321), 92(1986)

[36] NIPPON STEEL TECHNICAL REPORT No. 88 July 2003, UDC 699 .14 . 018. 295 - 415:629.11 . 011

[37] www.aksteel.com

[38] Uenishi, A., Suehiro, M., Kuriyama, Y., Usuda, M.: IBEC'96, Automo- tiveBody Interior \& Safety Systems. Automotive Technology Group Inc., Michigan USA, 1996, p. 